\title{
Günter Figal
}

\section{Verstehensfragen}

\author{
Studien zur phänomenologisch-hermeneutischen Philosophie
}

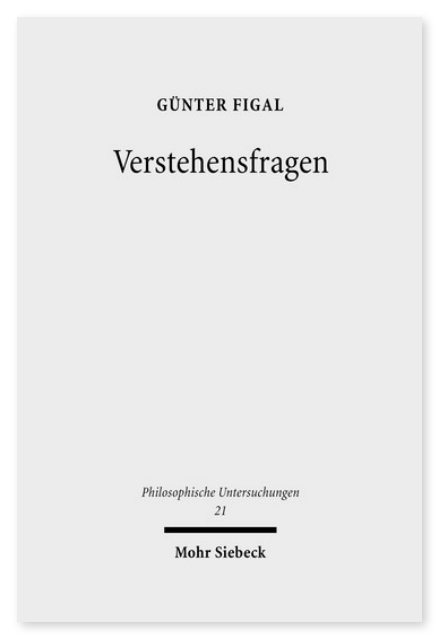

2009. X, 329 Seiten. PhU 21

ISBN 978-3-16-151332-9

DOI 10.1628/978-3-16-151332-9

eBook PDF 89,00€

ISBN 978-3-16-149805-3

Leinen $89,00 €$
Günter Figal widmet sich in seinen Studien der systematischen Ausarbeitung einer phänomenologisch-hermeneutischen Philosophie. Dabei fragt er in einigen Studien nach den Möglichkeiten der philosophischen Hermeneutik in phänomenologischer Perspektive. In anderen erläutert er anhand der Hermeneutik die Phänomenologie. Er betrachtet die Frage nach dem Verstehen als aufschlußreich für die Erfahrung des Phänomenalen. So erweist sich die Hermeneutik als ein Modell, an dem sich der phänomenologische Zugang zur Welt besonders gut verstehen läßt. Das Themenfeld des Bandes ist demnach zwischen der hermeneutischen und der phänomenologischen Fragestellung ausgespannt. Beide sollen sich in ihrer inneren Zusammengehörigkeit zu erkennen geben.

Die Gedankenentwicklung des Buches geht jedoch auf die Phänomenologie zu. Konsequent philosophisch ist die Hermeneutik nur als Phänomenologie. Nur phänomenologisch vermag die Hermeneutik dem traditionellen, zwar oft bestrittenen, aber niemals widerlegten Anspruch der Philosophie auf Voraussetzungslosigkeit zu entsprechen.

Phänomenologie ist ursprüngliches Verstehen, wie es sich in der aufzeigenden Beschreibung, im unbefangenen Hinsehen auf das, was sich zeigt, einstellt.

In dem vorliegenden Band nimmt Günter Figal den Ansatz des 2006 erschienenen Buches »Gegenständlichkeit. Das Hermeneutische und die Philosophie« auf und entwickelt inn weiter.

Günter Figal Geboren 1949; 1989-2002 Professor für Philosophie an der Universität Tübingen; 2002-17 Professor für Philosophie an der Universität Freiburg i.Br.; seit 2017 emeritiert.
Jetzt bestellen:

https://mohrsiebeck.com/buch/verstehensfragen-9783161513329?no_cache=1

order@mohrsiebeck.com

Telefon: +49 (0)7071-923-17

Telefax: $+49(0) 7071-51104$ 